\title{
Pengaruh Penerapan Positive Behaviour Support terhadap Pengembangan Budaya Inklusi
}

\author{
Made Dharmawan Rama Adhyatma' \\ Fakultas Psikologi Universitas Katolik Widya Mandala
}

Muryantinah Mulyo Handayani

Fakultas Psikologi Universitas Airlangga

\begin{abstract}
This study aimed to examine whether there was a positive effect of implementation of behavior support againt development of inclusive culture. Inclusive culture means a set of values and behaviors that reflect the efforts to realize the goal of inclusive schools, which gave equal rights for all children to receive educational services. Therefore, they could develop their capabilities to the fullest. Participants in this study were 243 students and the sampling technique was cluster random sampling. Data collection tools were inclusive culture scale which developed by researcher based on Booth and Ainscow's (2002) index for inclusion and positive behavior support intervention in the form of psychoeducation and token economy. Data analysis was performed using Wilcoxon signed ranks test with the help of SPSS 16.0 for windows. Result of this study indicated that postive behavior support had moderately significant effect to inclusive culture $(r=0.38, p<0.05)$.
\end{abstract}

Key words: inclusive culture, positive behavior support.

\begin{abstract}
Abstrak
Penelitian ini bertujuan untuk meneliti apakah ada pengaruh penerapan positive behavior support terhadap pengembangan budaya inklusi Surabaya. Budaya inklusi yang digunakan dalam penelitian ini adalah sekumpulan nilai dan perilaku yang mencerminkan usaha untuk mewujudkan tujuan sekolah inklusi, yaitu memberikan hak yang sama bagi seluruh anak untuk mendapatkan layanan pendidikan agar mereka bisa mengembangkan kemampuannya secara maksimal. Penelitian ini dilakukan pada 243 siswa. Teknik sampling yang digunakan adalah cluster random sampling. Alat pengumpulan data berupa skala psikologis, yaitu skala budaya inklusi yang disusun oleh peneliti mengacu pada index for inclusion dari Booth dan Ainscow (2002). Analisis data dilakukan dengan teknik statistik Wilcoxon signed ranks test dengan bantuan program SPSS 16.0 for windows. Hasil penelitian ini menunjukkan bahwa Positive behavior support memiliki pengaruh yang cukup signifikan untuk meningkatkan budaya inklusi ( $r=0.38, p<0.05)$.
\end{abstract}

Kata Kunci: budaya inklusi, positive behavior support.

Korespondensi: ${ }^{1}$ Fakultas Psikologi Universitas Katolik Widya Mandala, Jl. Dinoyo 42-44, Surabaya 60265, ${ }^{2}$ Fakultas Psikologi Universitas AirlanggaKampus B UNAIR - Jl. Airlangga 4-6, Surabaya 60286, Email: rama.made@gmail.com², muryantinah.mulyo@psikologi.unair.ac.id ${ }^{2}$ 


\section{PENDAHULUAN}

Kasus kekerasan pada anak akhir-akhir ini cukup mencuri perhatian masyarakat di Indonesia. Bahkan beberapa kasus kekerasan terjadi di sekolah dimana sekolah seharusnya menjadi tempat yang aman dan nyaman bagi anak untuk belajar. Badan Pusat Statistik mencatat (2009) menunjukkan bahwa dari seluruh laporan kasus kekerasan, 30\% di antaranya dilakukan oleh anak-anak dan $48 \%$ terjadi di lingkungan sekolah dengan motif dan kadar yang bervariasi. Child Protection Plan Indonesia melakukan survei tentang perilaku kekerasan di sekolah yang dilakukan di Jakarta, Yogyakarta, Surabaya, dan Bogor dengan melibatkan 1.500 siswa SMA dan 75 guru. Hasilnya, $67.9 \%$ menganggap terjadi kekerasan di sekolah, berupa kekerasan verbal, psikologis, dan fisik. Pelaku kekerasan pada umumnya adalah sesama siswa yaitu teman, kakak kelas, dan adik kelas (Aziz, 2011).

Smith (2006) mengungkapkan bahwa pendidikan inklusi adalah model pendidikan yang memungkinkan anak berkebutuhan khusus dapat berinteraksi langsung dengan siswa yang tidak memiliki hambatan khusus sehingga mampu meningkatkan ketrampilan sosial dan motivasinya dalam belajar. Sedangkan di Indonesia sendiri, pendidikan inklusi adalah model pendidikan yang memberikan kesempatan bagi anak berkebutuhan khusus untuk mendapat layanan pendidikan khusus yang bertempat di sekolah umum (Dinas Pendidikan Kota Surabaya, 2013). Tapi permasalahannya adalah siswa berkebutuhan khusus sendiri rentan untuk mendapatkan perlakuan yang tidak layak dari teman-temannya yang tidak memiliki kekhususan.

Permasalahan di atas muncul disebabkan oleh kurangnya upaya preventif dari pihak sekolah. Upaya preventif menurut Booth dan Ainscow (2002) adalah dengan menciptakan sebuah budaya inklusi agar para siswa dapat menginternalisasi nilai-nilai inklusi kedalam perilaku yang positif. Selama ini sekolah hanya banyak mengembangkan peraturan dan kemampuan guru dalam praktik inklusi (Mangunsong, 2009), namun tidak banyak menyentuh aspek nilai-nilai inklusi yang justru jika diinternalisasi dan dilakukan maka akan lebih efektif mengurangi jumlah kekerasan yang dialami oleh siswa berkebutuhan khusus.

Program yang efektif untuk menciptakan budaya inklusi adalah dengan membuat program positive behavior support (PBS) karena PBS sendiri merupakan suatu metode intervensi yang dilakukan bersama-sama dalam level sekolah dan bisa menciptakan sebuah budaya yang bersifat positif (Sailor, dkk., 2009). Penjelasan tersebut diperkuat oleh penelitian yang dilakukan oleh Vincent dan Tobin (2011). Mereka melakukan penelitian terhadap sebuah sekolah inklusi yang menerapkan PBS dalam level sekolah. Mereka menerapkan target berperilaku positif di berbagai tempat termasuk di kelas, kantin, kamar mandi, ruang guru, dan halte bus. Hasilnya menunjukkan bahwa penerapan PBS berkorelasi positif terhadap peningkatan perlakuan positif yang sesuai dengan budaya inklusi dari seluruh anggota sekolah terhadap siswa berkebutuhan khusus yang ada di sekolah inklusi. Selain itu, disimpulkan bahwa jumlah partisipasi siswa yang berasal dari etnis minoritas dan atau yang berkebutuhan khusus menjadi meningkat dalam berbagai kegiatan belajar.

Sementara itu penelitian lain tentang PBS juga dilakukan oleh Simonsen, dkk. (2010). Mereka melakukan sebuah penelitian terhadap suatu sekolah inklusi di California yang menerapkan PBS dalam level sekolah. Penerapan PBS yang dimaksud adalah dengan cara membuat sebuah target perilaku positif yang dilakukan oleh seluruh warga sekolah di berbagai tempat di sekolah. Lalu mereka merencanakan tiga buah perlakuan untuk menunjang munculnya target perilaku, yaitu guru memberi perlakuan yang dianggap bisa 
mestimulasi munculnya kesempatan agar target perilaku muncul, lalu respon positif jika muncul, dan respon jika perilaku yang muncul kebalikan dari target perilaku. Hasilnya menunjukkan perilaku positif di sekolah tersebut menjadimeningkat secara signifikan sehingga jumlah kasus siswa berkebutuhan khusus yang mengalami perlakuan negatif menjadi berkurang secara signifikan.

Tujuan penelitian ini adalah untuk menguji secara empiris pengaruh penerapan PBS dalam mengembangkan budaya inklusi. Adapun manfaat penelitian ini secara teoritis adalah menambah kajian teoritis tentangpengembangkan budaya inklusi di sekolah inklusi di Indonesia, khususnya Surabaya. Secara praktis, manfaatnya untuk pengembangan program-program peningkatan layanan pendidikan inklusi menjadi lebih efektif untuk dilaksanakan.

\section{METODE}

\section{Desain penelitian}

Penelitian ini menggunakan desain penelitian kuantitatif eksperimen. Pada penelitian ini, variabel bebasnya berupa intervensi dengan pendekatan positive behavior support sedangkan variabel terikatnya adalah budaya inklusi. Peneliti menggunakan salah satu desain penelitian pre-experimental design yaitu one group pretest-postestdesign. Penelitian ini menggunakansatu kelompok dengan mengukur variabel budaya inklusi sebelum intervensi (pretest), setelah itu memberikan intervensi $P B S$ dan terakhir setelah intervensi selesai maka budaya inklusi akan diukur kembali (Neuman, 2007). Hasil dari pengukuran berupa data kuantitatif akan diolah menggunakan program SPSS versi 16 for windows.

Adapun langkah-langkah eksperimennya adalah pertama membangun kesepahaman dan asesmen target perilaku, pengukuran variabel budaya inklusi sebelum intervensi (pretest),dan pelaksanaan intervensi $P B S$. Intervensi $P B S$ dilakukan dengan cara menetapkan target perilaku yang diharapkan sekolah, lalu mengajarkan target perilaku, menjalankan program pelaksanaan target perilaku, menentukan reinforcement positif, kemudian menentukan metode pengumpulan data, dan terakhir melakukan evaluasi terhadap data. Semua hal tersebut dilakukan dalam level sekolah secara bersama-sama. Media implementasi $P B S$ biasanya dilakukan melalui psikoedukasi dan token ekonomi (Sailor, dkk., 2009). Kemudian setelah pelaksanaan intervensi, dilakukan pengukuran variabel budaya inklusi dan terakhir melaksanakan posttest.

\section{Populasi dan sampling}

Populasi dalam penelitian ini adalah siswa di SMA X Surabaya. Populasi dalam penelitian ini memiliki kriteria-kriteria agar homogen. Kriteria partisipan dalam penelitian ini adalah: (1) siswa aktif di SMA X, (2) tingkat pendidikan di kelas X. Teknik sampling yang digunakan pada penelitian ini adalah non-probability sampling.

Sampel dipilih berdasarkan kriteria tertentu yang sesuai dengan konteks penelitian. Peneliti memilih kelas X sebagai sampel dengan alasan siswa di tingkat tersebut masih dalam tahap beradaptasi dengan budaya sekolah karena belum lama bersekolah di SMA X. Kemudian peneliti memilih secara acak siswasiswa kelas X yang akan dikenakan perlakuan dan dijadikan sampel penelitian. Penelitian ini menggunakan observasi sebagai alat untuk mengukur variabel budaya inklusi dalam aspek perilaku. Target perilaku dalam observasi ini didapatkan berdasarkan hasil FGD yang telah disesuaikan dengan teori budaya inklusi yang dikemukakan oleh Booth dan Ainscow (2002).

\section{HASIL PENELITIAN}


Tabel 1.

Tabel Hasil Pengukuran Perilaku Budaya Inklusi Sebelum Intervensi (Pretest)

\begin{tabular}{lccc}
\hline Target Perilaku & Observasi $\mathbf{1}$ & Observasi 2 & Observasi $\mathbf{3}$ \\
\hline $\begin{array}{l}\text { Siswa reguler duduk bersama siswa } \\
\text { berkebutuhan khusus saat di kelas }\end{array}$ & - & - & $\sqrt{ }$ \\
$\begin{array}{l}\text { Menyapa semua siswa termasuk } \\
\text { siswa berkebutuhan khusus }\end{array}$ & $\sqrt{ }$ & - & - \\
$\begin{array}{l}\text { Berbicara dengan suara yang } \\
\text { secukupnya ketika berada di kelas }\end{array}$ & - & - & - \\
$\begin{array}{l}\text { Membantu siswa berkebutuhan } \\
\text { khusus jika diperlukan }\end{array}$ & - & - & - \\
$\begin{array}{l}\text { Menjelaskan kembali materi kepada } \\
\text { siswa yang berkebutuhan khusus }\end{array}$ & - & & - \\
\hline
\end{tabular}

Observasi sebelum intervensi dalam penelitian ini dilakukan tiga kali dalam satu hari. Observasi di lakukan di tiga kelas yang berbeda dan tiga jam pelajaran yang berbeda. Hasilnya, seperti yang tersaji dalam tabel 1, menunjukkan bahwa perilaku yang muncul hanya siswa reguler duduk bersama siswa berkebutuhan khusus dan perilaku menyapa semua siswa termasuk siswa berkebutuhan khusus. Total perilaku yang muncul rata-rata o.67 atau kurang dari satu di setiap observasi. Berdasarkan nilai tersebut dapat disimpulkan bahwa kemunculan perilaku budaya inklusi sebelum diberikan intervensi PBS tergolong rendah. berkebutuhan khusus cenderung meningkat dari hari pertama sampai ke hari 14. Meskipun sempat menurun di hari ke 10, namun empat hari terakhir berikutnya siswa bisa memunculkan perilaku tersebut secara maksimal atau 40 kali dalam sehari. Data tersebut juga diperkuat oleh item nomor 37 pada alat ukur budaya inklusi dimana terjadi peningkatan skor dan rata-rata. Pada pretest skor aitem ini adalah 722 dengan rata-rata 2.8 atau dalam taraf jarang, meningkat menjadi 844 dengan rata-rata 3.5 atau berada dalam taraf sering muncul.

Berdasarkan observasi yang tersaji datanya di tabel 3, didapatkan bahwa kemunculan perilaku menjelaskan kembali materi kepada

Tabel 2.

Tabel Jumlah Perilaku Duduk dengan Siswa Berkebutuhan Khusus Setelah PBS (Postest)

\begin{tabular}{lcccccccccccccccc}
\hline Hari & $\mathbf{1}$ & $\mathbf{2}$ & $\mathbf{3}$ & $\mathbf{4}$ & $\mathbf{5}$ & $\mathbf{6}$ & $\mathbf{7}$ & $\mathbf{8}$ & $\mathbf{9}$ & $\mathbf{1 0}$ & $\mathbf{1 1}$ & $\mathbf{1 2}$ & $\mathbf{1 3}$ & $\mathbf{1 4}$ & Total & Mean \\
\hline Jumlah & 36 & 35 & 36 & 37 & 39 & 40 & 40 & 40 & 40 & 39 & 40 & 40 & 40 & 40 & 542 & 38.71 \\
\hline
\end{tabular}

Tabel 3. Tabel Jumlah

Perilaku Menjelaskan Kembali Materi pada Siswa Berkebutuhan Khusus Setelah PBS (Postest)

\begin{tabular}{lcccccccccccccccc}
\hline Hari & $\mathbf{1}$ & $\mathbf{2}$ & $\mathbf{3}$ & $\mathbf{4}$ & $\mathbf{5}$ & $\mathbf{6}$ & $\mathbf{7}$ & $\mathbf{8}$ & $\mathbf{9}$ & $\mathbf{1 0}$ & $\mathbf{1 1}$ & $\mathbf{1 2}$ & $\mathbf{1 3}$ & $\mathbf{1 4}$ & Total & Mean \\
\hline Jumlah & 32 & 32 & 33 & 33 & 35 & 33 & 34 & 34 & 35 & 34 & 35 & 35 & 35 & 36 & 476 & 34 \\
\hline
\end{tabular}

Berdasarkan hasil observasi yang tersaji dalam tabel 2 dapat disimpulkan bahwa kemunculan perilaku duduk dengan siswa siswa berkebutuhan khusus meningkat dari hari pertama sampai hari ke 14. Hanya saja memang tidak maksimal mencapai angka 40. Hasil ini 
diperkuat melalui data aitem nomor 14 pada alat ukur dimana skor untuk item ini meningkat dari awalnya 604 dengan rata-rata 2.5 menjadi 708 dengan rata-rata 3 . Awalnya siswa merasa jarang terjadi maka setelah intervensi meningkat dan merasa sering terjadi. Hasil observasi menunjukkan bahwa kendala yang terjadi adalah siswa reguler kesulitan ketika harus menjelaskan materi yang bergambar, terutama kepada siswa tuna netra di beberapa kelas. Mata pelajaran yang sulit untuk dijelaskan biasanya adalah bidang IPA dan matematika yang materinya banyak menggunakan gambar. mengumpulkan beberapa tugas prakarya, sehingga siswa tidak melakukan target perilaku. Perilaku yang tercatat muncul adalah membantu siswa tuna netra dan tuna daksa ke kamar mandi, membantu siswa autis untuk tenang, menenangkan siswa autis yang jalanjalan di kelas, meminjamkan alat tulis dan buku pelajaran ketika siswa ABK tidak membawa dua barang tersebut.

Berdasarkan observasi dalam tabel 5, didapatkan bahwa meskipun mengalami peningkatan dari hari pertama sampai ke 14. Hal ini juga diperkuat melalui peningkatan skor

Tabel 4.

Tabel Jumlah Perilaku Membantu Siswa Berkebutuhan Khusus Setelah PBS (Postest)

\begin{tabular}{lcccccccccccccccc}
\hline Hari & $\mathbf{1}$ & $\mathbf{2}$ & $\mathbf{3}$ & $\mathbf{4}$ & $\mathbf{5}$ & $\mathbf{6}$ & $\mathbf{7}$ & $\mathbf{8}$ & $\mathbf{9}$ & $\mathbf{1 0}$ & $\mathbf{1 1}$ & $\mathbf{1 2}$ & $\mathbf{1 3}$ & $\mathbf{1 4}$ & Total & Mean \\
\hline Jumlah & 37 & 37 & 38 & 39 & 40 & 40 & 40 & 40 & 37 & 38 & 39 & 40 & 40 & 40 & 545 & 38.92 \\
\hline
\end{tabular}

Tabel 5.

Tabel Jumlah Perilaku Bersuara Secukupnya di Kelas Setelah PBS (Postest)

\begin{tabular}{lcccccccccccccccc}
\hline Hari & $\mathbf{1}$ & $\mathbf{2}$ & $\mathbf{3}$ & $\mathbf{4}$ & $\mathbf{5}$ & $\mathbf{6}$ & $\mathbf{7}$ & $\mathbf{8}$ & $\mathbf{9}$ & $\mathbf{1 0}$ & $\mathbf{1 1}$ & $\mathbf{1 2}$ & $\mathbf{1 3}$ & $\mathbf{1 4}$ & Total & Mean \\
\hline Jumlah & 29 & 27 & 30 & 32 & 33 & 33 & 34 & 33 & 35 & 35 & 37 & 38 & 38 & 38 & 472 & 33.71 \\
\hline
\end{tabular}

Berdasarkan observasi di tabel 4, didapatkan bahwa tujuh hari siswa bisa maksimal memunculkan target perilaku membantu siswa berkebutuhan khusus ketika dibutuhkan sebanyak 40 kali. Kecenderungan kemunculan perilaku memang meningkat dari hari pertama sampai ke 14. Hanya saja ada penurunan di hari ke 9, 10, dan 11. Penemuan ini juga diperkuat melalui aitem nomor 8 dimana terjadi peningkatan skor yang awalnya 7.85 atau rata-rata 3.2 meningkat menjadi menjadi 829 atau rata-rata 3.4. Hasil observasi dan wawancara menunjukkan bahwa pada hari tersebut di beberapa kelas sedang sibuk total aitem nomor 9 pada alat ukur. Saat pretest skor total adalah 675 atau rata-rata 2.7 meningkat menjadi 781 atau rata-rata 3.2 saat setelah intervensi. Hal ini menunjukkan ada peningkatan kemunculan dalam perilaku bersuara secukupnya di kelas, dimana awalnya mereka merasa jarang namun setelah intervensi meningkat menjadi sering. Tapi tabel 5 juga menunjukkan perilaku berbicara dengan suara secukupnya di kelas tidak pernah muncul secara maksimal dalam 40 kali kesempatan di tiap harinya. Berdasarkan observasi guru didapat bahwa hal ini disebabkan oleh adanya kecenderungan siswa untuk bercanda di dalam

Tabel 6.

Tabel Jumlah Perilaku Memberi Salam pada Guru, Siswa dan Karyawan Setelah PBS (Postest)

\begin{tabular}{lcccccccccccccccc}
\hline Hari & $\mathbf{1}$ & $\mathbf{2}$ & $\mathbf{3}$ & $\mathbf{4}$ & $\mathbf{5}$ & $\mathbf{6}$ & $\mathbf{7}$ & $\mathbf{8}$ & $\mathbf{9}$ & $\mathbf{1 0}$ & $\mathbf{1 1}$ & $\mathbf{1 2}$ & $\mathbf{1 3}$ & $\mathbf{1 4}$ & Total & Mean \\
\hline Jumlah & 36 & 36 & 36 & 36 & 37 & 36 & 38 & 38 & 38 & 40 & 40 & 40 & 40 & 40 & 531 & 37.97 \\
\hline
\end{tabular}


kelas sehingga sulit untuk mengontrol suaranya ketika bercanda. Beberapa kali suara tersebut cukup mengganggu guru yang sedang menjelaskan dan membuat kelas menjadi gaduh.

Berdasarkan observasi yang tersaji di tabel 6, didapatkan bahwa kemunculan perilaku memberi salam kepada guru, siswa dan karyawan memiliki kecenderungan yang meningkat mulai dari hari pertama hingga terakhir. Hal ini juga diperkuat dari data alat ukur item nomor 3. Terjadi peningkatan frekuensi dari item ini dimana saat pretest skor adalah 730 atau rata-rata 3 yang berarti mereka cukup sering melakukan, meningkat menjadi 788 saat post test atau rata-rata 4 yang berarti mereka menjadi sangat sering melakukan target perilaku ini. Berdasarkan hasil observasi dan wawancara didapatkan bahwa perilaku ini cukup mudah dimunculkan oleh siswa karena mereka sepakat dengan teman sekelasnya untuk menyapa setiap guru atau karyawan yang masuk ke kelas. Perilaku memberi salam yang muncul selain itu adalah siswa menyapa siswa ABK dari kelas lain ketika lewat di depan kelas, bahkan beberapa kali mereka mengajak siswa ABK untuk masuk ke kelas dan mengajaknya berbicara atau bermain bersama.

Hasil target perilaku membuat poster sosialisasi tentang salah satu jenis kekhususan dan budaya inklusi menunjukkan mulai tumbuhnya pemahaman hak yang sama bagi semua siswa termasuk siswa berkebutuhan khusus dalam memperoleh layanan pendidikan. Poster karya siswa menjelaskan bahwa anak berkebutuhan khusus juga memiliki kesempatan untuk bisa sukses dan berprestasi. Dalam hal ini mereka berusaha menjelaskan tentang autisme. Isi poster tersebut juga mengajak warga sekolah untuk berpandangan positif pada autisme dan berusaha memunculkan optimisme bahwa anak yang mengalami autisme juga berperan serta dalam meajukan bangsa ini melalui ciri khas kelebihan-kelebihan yang dimiliki dalam autisme.

Dalam target perilaku membuat poster ini tidak ada penilaian yang membuat adanya data kuantitatif untuk menghitung besarnya perubahan. Namun dari hasil analisis terhadap isi dari beberapa poster tersebut, maka dapat disimpulkan beberapa hal penting yang berkaitan dengan budaya inklusi, yaitu; (1) menampakkan perubahan pemahaman ke arah yang benar tentang pengertian inklusi dan anak berkebutuhan khusus. Siswa sudah tidak menyebut temannya yang berkebutuhan khusus sebagai anak inklusi lagi; (2) munculnya persepsi yang positif terhadap anak berkebutuhan khusus. Mereka mulai memunculkan pemahaman bahwa anak berkebutuhan khusus akan memiliki minat dan bakatnya sendiri yang mungkin tidak diketahui oleh orang awam; (3) pemahaman yang muncul saat psikoedukasi bahwa anak berkebutuhan khusus adalah anak yang kelainan mental dan cacat sudah tidak tampak. Mereka mulai memperhalus dengan menyebut kemampuan

Tabel 7.

Perbandingan Jumlah Kemunculan Target Perilaku Setelah Intervensi

\begin{tabular}{lcc}
\hline Target Perilaku & $\begin{array}{c}\text { Frekuensi Total } \\
\text { Selama 14 Hari }\end{array}$ & Rata-Rata \\
\hline Membantu siswa berkebutuhan khusus ketika dibutuhkan & 545 & 38,92 \\
Duduk dengan siswa berkebutuhan khusus & 542 & 38,71 \\
Memberi salam kepada guru, siswa dan karyawan & 531 & 37,97 \\
Menjelaskan kembali materi pada siswa berkebutuhan khusus & 476 & 34,00 \\
Berbicara dengan suara yang secukupnya ketika di kelas & 472 & 33,17 \\
\hline
\end{tabular}


yang berbeda dan bukan berarti tidak mampu; (4) muncul penerimaan atas kehadiran siswa berkebutuhan khusus. Hal itu tampak pada kalimat-kalimat persuasif yang positif kepada pembaca agar mulai bisa memandang dan memperlakukan anak berkebutuhan sama dengan teman yang lain bahwa mereka juga butuh teman sama seperti orang pada umumnya.

Berdasarkan tabel 7 dan penjelasan sebelumnya maka dapat disimpulkan bahwa target perilaku yang paling sering untuk muncul selama proses intervensi adalah perilaku membantu siswa berkebutuhan khusus dimana perilaku ini muncul sebanyak 545 kali dalam 14 hari atau rata-rata muncul 38.92 kali dalam satu hari. Perilaku membantu siswa berkebutuhan khusus yang muncul adalah;

1. Menuntun siswa tuna netra ke kamar mandi;

2. Menuntun siswa tuna daksa ke kamar mandi;

3. Membantu siswa autis untuk tenang ketika sedang duduk;

4. Menenangkan siswa autis yang jalanjalan di kelas;

5. Meminjamkan alat tulis ketika siswa ABK tidak membawa; dan

6. Meminjamkan buku pelajaran ketika siswa ABK tidak membawa.

Target perilaku kedua yang paling sering muncul adalah siswa reguler duduk dengan siswa berkebutuhan khusus. Dalam asesmen awal diperoleh data bahwa selama ini siswa berkebutuhan khusus duduk sendiri, hanya sesekali ditemani guru pendamping. Namun selama proses intervensi terjadi perubahan dimana siswa reguler secara bergantian duduk menemani siswa berkebutuhan khusus ketika pelajaran berlangsung. Target perilaku ini muncul sebanyak 542 kali dalam 14 hari atau rata-rata 38.71 kali dalam sehari. Hasil observasi guru menyebutkan bahwa mereka tidak hanya duduk bersama, namun juga salingberinteraksi seperti bercanda, menjelaskan materi, atau membicarakan hal-hal tertentu.

Target perilaku ketiga yang paling sering muncul adalah memberi salam kepada guru, siswa, dan karyawan dimana perilaku ini muncul 531 kali dalam 14 hari atau rata-rata 37.97 kali dalam sehari. Perilaku ini dilakukan oleh siswa pada saat guru atau karyawan masuk ke kelas mereka. Perilaku ini juga muncul ketika ada siswa berkebutuhan khusus yang lewat di depan kelas.

Target perilaku yang frekuensi kemunculannya sedikit sulit adalah menjelaskan materi kepada siswa berkebutuhan khusus. Perilaku ini muncul sebanyak 476 kali dalam 14 hari atau rata-rata 34 kali dalam satu hari. Perilaku ini cukup sulit untuk muncul karena beberapa siswa reguler di kelas tertentu kesulitan ketika menjelaskan materi bergambar kepada siswa tuna netra, terutama mata pelajaran IPA dan matematika. Selain itu kesulitan yang muncul menurut siswa reguler adalah ketika harus membagi konsentrasi untuk memperhatikan atau memahami materi dengan harus menjelaskan kepada siswa berkebutuhan khusus sehingga terkadang mereka mengaku tidak sempat untuk menjelaskan.

Target perilaku yang paling sulit untuk muncul adalah berbicara dengan suara secukupnya ketika berada di kelas. Perilaku ini muncul sebanyak 472 kali dalam 14 hari dan rata-rata muncul 33.71 kali dalam sehari. Menurut hasil observasi guru, hal ini disebabkan oleh ada satu kelas yang memiliki kecenderungan tinggi untuk bercanda di keras dengan celetukan-celetukan dengan suara yang cukup keras dan itu cukup mengganggu jalannya pelajaran.

Tabel 8 menunjukkan bahwa rata-rata kemunculan perilaku saat pretest adalah 0.67 atau perilaku yang muncul rata-rata kurang dari satu di setiap observasi. Berdasarkan nilai tersebut dapat disimpulkan bahwa kemunculan perilaku budaya inklusi sebelum diberikan 
Tabel 8.

Perbandingan Perilaku Budaya Inklusi Pretest dan Postest

\begin{tabular}{lcc}
\hline Target Perilaku & $\begin{array}{c}\text { Frekuensi } \\
\text { Postest }\end{array}$ & $\begin{array}{c}\text { Frekuensi } \\
\text { Pretest }\end{array}$ \\
\hline Membantu siswa berkebutuhan khusus ketika dibutuhkan & 545 & 0 \\
Duduk dengan siswa berkebutuhan khusus & 542 & 1 \\
Memberi salam kepada guru, siswa dan karyawan & 531 & 1 \\
Menjelaskan kembali materi pada siswa berkebutuhan khusus & 476 & 0 \\
Berbicara dengan suara yang secukupnya ketika di kelas & 472 & 0 \\
\hline Total & $\mathbf{2 5 6 6}$ & $\mathbf{2}$ \\
\hline Kesempatan observasi & 560 & $\mathbf{3}$ \\
\hline Rata-rata & $\mathbf{4 . 5 8}$ & $\mathbf{0 . 6 7}$ \\
\hline
\end{tabular}

intervensi PBS tergolong rendah. Sedangkan rata-rata kemunculan perilaku saat postest adalah 4.58. Angka tersebut menunjukkan bahwa hampir semua target perilaku selalu muncul di setiap observasi sehingga dapat disimpulkan bahwa kemunculan perilaku budaya inklusi setelah diberikan intervensi PBS tergolong tinggi.

Berdasarkan tabel 8 juga menunjukkan bahwa rata-rata kemunculan target perilaku budaya inklusi sebelum intervensi (o.67) lebih rendah jika dibandingkan dengan setelah intervensi (4.58). Hal tersebut menunjukkan bahwa memang terjadi peningkatan kemunculan perilaku budaya inklusi pada siswa setelah mereka dikenai intervensi PBS.

Setelah dilakukan uji Wilcoxon signed ranks, menghasilkan nilai $p<0.005$, sehingga dapat disimpulkan bahwa $\mathrm{H}_{\mathrm{o}}$ ditolak. Dengan demikian dapat disimpulkan bahwa ada perbedaan yang signifikan antara hasil dari pretest dan post test terhadap variabel budaya inklusi.

Kemudian untuk mengetahui seberapa besar pengaruh intervensi terhadap variabel budaya inklusi maka diperlukan perhitungan effect size. Caranya adalah membagi skor $\mathrm{Z}$ dengan akar kuadrat total jumlah case yang dianalisis $(\mathrm{N})$. Dalam penelitian ini jumlah case adalah 243 dengan dua kali pengukuran saat pretest dan post test sehingga total $\mathrm{N}$ adalah 486. Berdasarkan perhitungan, didapatkan bahwa nilai effect size data penelitian ini adalah o.38. Nilai tersebut menunjukkan bahwa intervensi $P B S$ memiliki dampak yang tergolong moderate effect atau cukup.

\section{DISKUSI}

Hasil uji beda menggunakan Wilcoxon Signed Ranks Test menunjukkan bahwa adanya perbedaan yang signifikan pada variabel budaya inklusi ketika sebelum dengan sesudah diberikan intervensi PBS Perbedaannya pun bersifat positif karena hasil rata-rata skor budaya inklusi setelah intervensi lebih besar dibandingkan dengan skor sebelum intervensi. Kemudian besarnya perubahan yang terjadi tergolong sedang. Hasil tersebut mendukung penelitian dari Vincent dan Tobin (2011) yang menyimpulkan bahwa intervensi $P B S$ membantu komunitas sekolah untuk dapat mengembangkan budaya inklusi.

Pless dan Maak (2004) mengemukakan bahwa upaya pertama yang harus dilakukan untuk menciptakan budaya inklusi adalah melakukan rekognisi tentang permasalahanpermasalahan yang masih sering salah dipahami. Ketika seseorang telah memandang keberagaman sebagai sesuatu yang positif maka akan lebih mudah untuk saling bekerja sama 
dan produktif dalam mengeluarkan potensi yang dimiliki dalam mencapai tujuan bersama.

Hasil penelitian Pless dan Maak (2004) tersebut juga terjadi dalam penelitian ini. Penelitian ini menunjukkan bahwa proses tahapan pelaksanaan $P B S$ yang dilakukan cukup berpengaruh terhadap perkembangan budaya inklusi baik dalam aspek kognitif maupun perilaku. Pada aspek kognitif tampak ada perubahan pemahaman dari siswa tentang inklusi, anak berkebutuhan khsusus, dan budaya inklusi. Pada aspek ini persepsi negatif siswa reguler terhadap siswa berkebutuhan khusus mulai berubah dan menjadi lebih positif. Hal ini disebabkan pada saat proses psikoedukasi, siswa reguler telah diberikan pemahaman bahwa anak berkebutuhan khusus tidak selamanya identik dengan ketidakmampuan, namun ada juga yang bisa berprestasi melebihi orang yang dikatakan normal.

Pada aspek perilaku tampak bahwa enam target perilaku mengalami peningkatan bila dibandingkan pada saat sebelum intervensi. Kesepahaman yang diberikan kepada siswa saat FGD dan psikoedukasi memunculkan semangat yang sama untuk melaksanakan $P B S$ agar mereka bisa memperlakukan semua warga sekolah dengan baik. Menurut Dunlap, dkk. (2009) hal tersebut disebabkan karena intervensi $P B S$ dilakukan secara bersama-sama dan komperehensif dalam level sekolah sehingga semua warga sekolah termasuk siswa memiliki standar perilaku yang sama.

Hal yang sama diungkapkan oleh Walker, dkk. (2005), poin terpenting PBS dalam membentuk perilaku yang baik adalah kebersamaan. Ketika semua pihak memiliki kesepahaman tentang pentingnya target perilaku yang harus dilakukan, maka akan ada energi positif yang menyebar kepada semua anggota sekolah untuk bersama-sama melaksanakan target perilaku.

Hal ini terlihat saat intervensi $P B S$. Karakteristik kelas yang berhasil mengumpulkan token paling banyak dan berhak mendapatkan back-up reinforcer adalah kelas yang anggotanya terlihat antusias menjalankan intervensimulai dari proses psikoedukasi sampai dengan token ekonomi. Menurut Miltenberger (2012) hal ini disebabkan oleh adanya perubahan fungsi perilaku dari siswa dalam melaksanakan budaya inklusi saat sebelum dan sesudah intervensi. Miltenberger (2012) mengungkapkan bahwa faktor motivasi sangat mempengaruhi perilaku dari seseorang. Hal ini yang diubah dalam intervensi token ekonomi sehingga siswa bisa memaknai fungsi perilaku menjadi lebih positif dan dapat mendorong munculnya perilaku budaya inklusi yang diharapkan.

Selain faktor eksternal yang telah dijelaskan sebelumnya, menurut penelitian Marcoulides, dkk. (2005), faktor internal juga berpengaruh dalam pembentukan suatu budaya dalam sekolah. Seseorang yang mampu berkomunikasi dengan baik dan fleksibel maka akan mudah mempengaruhi orang lain untuk memunculkan perilaku yang diharapkan. Hal ini terlihat ketika proses intervensi dalam penelitian ini. Perwakilan kelas yang mengikuti proses psikoedukasi benar-benar bisa menyampaikan pemahamannya tentang budaya inklusi kepada temannya yang lain satu kelas. Dampaknya semua penugasan dilakukan dengan tepat waktu dan hasilnya tergolong baik. Siswa kelas ini juga benar-benar melibatkan temannya yang berkebutuhan khusus dalam pergaulan sehari-hari. Bahkan ada seorang siswa berkebutuhan khusus dari kelas lain yang setiap hari datang ke kelas ini dan bermain bersama. Tampak bahwa siswa di kelas ini cukup luwes dalam berkomunikasi sehingga bisa teman berkebutuhan yang tidak sekelas dengan mereka untuk berinteraksi dan sekedar bermain bersama mereka.

Thomas, dkk. (1998) menambahkan bahwa semua siswa di sekolah inklusi harus bisa menunjukkan perilaku yang positif agar bisa mendukung terciptanya lingkungan yang 
kondusif. Perilaku ini harus dimunculkan di berbagai seting tempat di sekolah, seperti kelas, kantin, dan kamar mandi. Hal ini juga terjadi dalam penelitian ini. Berdasarkan hasil observasi didapatkan bahwa terjadi peningkatan rata-rata frekuensi perilaku budaya inklusi saat sesudah intervensi diberikan. Perilaku yang paling sering muncul adalah membantu siswa berkebutuhan khusus. Perilaku membantu siswa berkebutuhan khusus yang muncul adalah menuntun siswa tuna netra ke kamar mandi, menuntun siswa tuna daksa ke kamar mandi, membantu siswa autis untuk tenang ketika sedang duduk, menenangkan siswa autis yang jalan-jalan di kelas, dan meminjamkan alat tulis ketika siswa ABK tidak membawa. Lalu target perilaku kedua yang paling sering muncul adalah siswa reguler duduk dengan siswa berkebutuhan khusus. Dalam asesmen awal diperoleh data bahwa selama ini siswa berkebutuhan khusus duduk sendiri, hanya sesekali ditemani guru pendamping. Namun selama proses intervensi terjadi perubahan dimana siswa reguler secara bergantian duduk menemani siswa berkebutuhan khusus ketika pelajaran berlangsung.

Selain itu Thomas, dkk. (1998) juga menyebutkan siswa pada sekolah inklusi bisa mewujudkan pertemanan yang bersifat positif dalam pergaulan. Mereka harus bisa berteman tanpa membedakan suku, ras, agama, atau kekhususan tertentu. Dalam penelitian didapatakan data observasi bahwa mulai muncul inisiatif dari siswa yang tergolong normal untuk mengajak siswa berkebutuhan khusus untuk terlibat dalam pergaulan mereka. Siswa berkebutuhan khusus tidak lagi dijauhi oleh temannya yang normal.

Khusus dalam konteks berkebutuhan khusus, Thomas, dkk. (1998) juga mengungkapkan bahwa siswa yang dianggap normal bisa menjadi contoh dan membantu perkembangan keterampilan sosial dari siswa yang berkebutuhan khusus. Dalam penelitian ini siswa yang tergolong normal berinisiatif memberikan contoh bagaimana memulai interaksi dengan seseorang, yaitu dimulai dengan menyapa dan mencoba memulai pembicaraan sederhana dengan topik hal yang disukai oleh siswa berkebutuhan khusus.

Dalam penerapan PBS level school wide ada dua faktor yang bisa mempengaruhi budaya inklusi. Dua faktor tersebut adalah waktu dan metode pengajaran target perilaku (Freeman, dkk., 2006).

Freeman, dkk. (2006) mengungkapkan faktor pertama yang berpengaruh adalah waktu. Untuk menerapkan PBS dalam level school wide memang membutuhkan waktu lebih dari satu tahun. Sedangkan pada penelitian ini proses intervensi hanya berlangsung selama satu bulan, sehingga hal ini bisa menjadi penyebab bahwa efek yang dihasilkan hanya tergolong sedang. Sebaiknya intervensi ini dilakukan dalam waktu satu tahun lebih dan berkelanjutan agar efeknya bisa lebih besar terhadap peningkatan budaya inklusi.

Meski begitu, setidaknya pada tahun pertama sudah dilakukan beberapa fondasi awal penerapan PBS, yaitu pembentukan tim intervensi dan pembuatan rancangan program mulai penetapan target perilaku, rancangan mekanisme pemberian reinforcement positif hingga cara pengumpulan data. Pada penelitian ini pembentukan pondasi awal tersebut sudah dilakukan. Tim intervensi sudah terbentukyang terdiri atas guru dan siswa. Kemudian rancangan mekanisme reinforcement positif dan pengumpulan data juga sudah dilakukan dalam proses intervensi, sehingga nantinya tim intervensi tinggal melanjutkan program yang telah dibuat.

Faktor kedua yang berpengaruh adalah metode pengajaran target perilaku. Target perilaku harus diajarkan pada seluruh anggota sekolah atau kepada seluruh siswa yang menjadi partisipan penelitian. Sedangkan pada penelitian ini, pengajaran target perilaku yang dilakukan lewat psikoedukasi hanya diikuti oleh 
dua orang perwakilan masing-masing kelas. Meskipun telah dibuat upaya penyebaran flyer panduan budaya inklusi, poster dan kontrak perilaku tapi ternyata tidak semua perwakilan bisa menerangkan informasi tersebut secara baik. Hal ini yang menyebabkan penyebaran pemahaman target perilaku kurang berjalan efektif sehingga efek yang dihasilkan oleh PBS terhadap budaya inklusi dalam penelitian ini hanya tergolong sedang (Freeman, dkk., 2006).

\section{SIMPULAN}

Hasil dari penelitian ini dapat disimpulkan bahwa intervensi $P B S$ memberikan pengaruh yang cukup signifikan untuk mengembangkan budaya inklusi. Penelitian ini tidak melakukan uji coba alat ukur sehingga alat ukur kurang mendapat evaluasi sebelum dikenakan kepada partisipan penelitian sesungguhnya. Berdasarkan hal tersebut maka untuk penelitian selanjutnya disarankan melakukan uji coba agar alat ukur yang akan dipakai pada penelitian sudah melewati proses evaluasi. Proses evaluasi tersebut diharapkan dapat meningkatkan kualitas alat ukuragar lebih memadai.

\section{SARAN}

Saran untuk pihak sekolah penyelenggara inklusi, yaitu; (1) mengingat saat ini penerapan budaya inklusi pada siswa sudah cukup baik, maka pihak sekolah disarankan untuk menjalankan kembali intervensi ini ketika siswa tahun ajaran baru masuk ke sekolah inklusi. Hal ini penting agar siswa baru bisa cepat beradaptasi dengan budaya inklusi yang ada di sekolah ini; (2) mengingat faktor lamanya waktu intervensi yang berpengaruh terhadap peningkatan budaya inklusi, maka sebaiknya pihak sekolah melaksanakan intervensi PBS ini secara berkelanjutan selama kurang lebih satu tahun pelajaran. Hal ini penting agar efek PBS terhadap peningkatan budaya inklusi bisa lebih besar; (3) metode pengajaran target perilaku dalam intervensi PBS sebaiknya dilakukan secara bersama di setiap kelas agar pengajaran bisa efektif dan semua siswa bisa memperoleh informasi secara jelas serta dapat memahami pentingnya target perilaku untuk dilakukan. Jika ini sudah dilakukan maka nantinya proses peningkatan budaya inklusi diharapkan bisa lebih besar.

\section{PUSTAKA ACUAN}

Ainscow, M. (1997). Towards inclusive schooling. British Journal of Special Education, 24, 3-6.

Aziz, N.A. (2011). Bullying sering dianggap sepele. Kompas [on-line]. Diakses pada tanggal 22 April 2013 dari http://edukasi.kompas.com/read/2011/04/o9/15512144/Bullying.Sering. Dianggap.Sepele

Azwar, S. (2009). Reliabilitas dan validitas. Yogyakarta: Pustaka Pelajar.

Azwar, S. (2010). Penyusunan skala psikologi. Yogyakarta: Pustaka Pelajar.

Booth, T., and Ainscow, M. (2002). Index for Inclusion: developing learning in schools. Centre for Studies on Inclusive Education.

Departemen Pendidikan Nasional. (2004). Undang-undang Republik Indonesia nomor 20 tahun 2003 tentang sistem pendidikan nasional. Diakses pada tanggal 23 April 2013 dari http://www.kemdiknas.go.id/kemdikbud/search/node/undang-undang\%2onomor $\% 2020 \% 202003$.

Departemen Pendidikan Nasional. (2007). Pedoman pelaksanaan sekolah inklusi.

Dinas Pendidikan dan Kebudayaan Kota Surabaya. (2013). Data dan alamat sekolah inklusifkota surabaya.

Dunlap, G. (2006). The applied behavior analytic heritage of PBS: A dynamic model of action-oriented research. Journal of Positive Behavior Interventions, 8, 5860. 
Dunlap, G., Carr, E.G., Horner, R.H., Zarcone, J.R., \& Schwartz, I. (2008). Positive behavior support and applied behavior analysis: A familial alliance. Journal of Behavior Modification, 32(5), 682-698.

Field, A. (2009). Discovering statistics using SPSS (third edition). Los Angeles: SAGE.

Freeman, R., Eber, L., Anderson, C., Irvin, L., Horner, R., Bounds, M., \& Dunlap, G. (2006). Building inclusive school culture using school-wide PBS: Designing effective individual support systems for students with signif icant disabilities. Research \& Practice for Persons with SevereDisabilities, 31(1), 4-17.

Hadi, dkk. (2008). Psikologi eksperimen. Surabaya:UP3 Psikologi Unair.

Luciano, S., and Savage, R.S. (2007). Bullying risk in children with learning Difficulties in Inclusive Educational Settings. Canadian Journal of SchoolPsychology, 22(1), 14-31.

Mangunsong, F. (2009). Psikologi dan pendidikan anak berkebutuhan khusus (Jilid 1). Jakarta: LPSP 3 UI.

Marcoulides, G.A., Heck, R.H., \& Papanastasiou, C. (2005). Student perceptions of school culture and achievement: Testing the invariance of a model. TheInternational Journal of Educational Management, 19, 140-152.

Miltenberger, R.G. (2012). Behaviour modifications: Principles and procedures (Fifth edition). Belmont: Wadsworth.

Neuman, W.L. (2007). Basics of social research: Qualitative and quantitativeapproaches (second edition). USA: Pearson Education, Inc.

Nurhasanah, N. (2009). Penerapan pendekatan kontekstual untuk meningkatkan kualitas pembelajaran pendidikan kewarganegaraan pada siswa SD laboratorium PGSD FIP UNJ. Jurnal Pendidikan Penabur, 8(12), 1-20.

Pallant, J. (2011). SPSS survival manual: A step by step guide to data analysis using SPSS (4th edition). Australia: Allen \& Unwin.

Pless, N. M., \& Maak, T. (2004). Building an inclusive diversity culture: Principles, processes and practice. Journal of Business Ethics, 54, 129-147.

Ponzetti, J. J. (2003). International encyclopedia of marriage and family. NewYork: Thomson-Gale Publishing.

Sailor, W. Dunlap, G., Sugai, G. and Horner, R. (2009) Handbook of PositiveBehavior Support. New York: Springer Science+Business Media, LLC.

Sarwono, S. W. (2004). Psikologi remaja. Jakarta: P.T. Raja Grafindo Persada.

Simonsen, B., Britton, L., \& Young, D. (2010). School-Wide Positive Behavior Support in an alternative school setting. Journal of Positive BehaviorInterventions, 12(3), 180-191.

Smith, D. (2006). Inklusi: Sekolah ramah untuk semua. Bandung: Nuansa.

Sukadji, S. (2003). Psikologi Pendidikan dan Psikologi Sekolah (Direvisi danDilengkapi). Jakarta: LPSP3 Fakultas Psikologi Universitas Indonesia.

Sunarto, H., \& Hartono, B. A. (2008). Perkembangan peserta didik. Jakarta: P.T. Rineka Cipta.

Thomas, G., Walker, D., \& Webb, J. (1998). The making of: The inclusive school. New York: Routledge.

UNESCO (1994). The UNESCO Salamanca Statement and Framework for Actionon Special Needs Education. Paris: UNESCO. Diakses pada tanggal 22April 2013, dari http://unesco.org/ education/educprog/sne/salamanc/stnteme.html

UNESCO. (2001). Open file on inclusive education: Support materials formanagers and administrators. Paris: UNESCO Inclusive Education. 
Pengaruh Penerapan Positive Behaviour Support terhadap Pengembangan Budaya Inklusi

Vincent, C.G., and Tobin, T.J. (2011). The relationship between implementation of School-Wide Positive Behavior Support (SWPBS) and disciplinary exclusion of students from various ethnic backgrounds with and without disabilities. Journal of Emotional and Behavioral Disorders, 19(4), 217-232.

Walker, B. A., Cheney, D., Stage, S., \& Blum, C. (2005). School-wide screening and positive behavior supports: Identifying and supporting students at-risk for school failure. Journal of Positive Behavior Interventions, 7, 194-204. 